J urra PerddkanBłæsacknSastra V dume12, Nomr 2, Oktdber 2012

\title{
RELASI ANTARTEKS DALAM PENGKAJIAN SASTRA
}

\author{
Sumiyadi \\ FPBS, Universitas Pendidikan Indonesia \\ Korespondensi: Jl. Dr. Setiabudhi 229 Bandung 40154 \\ e-mail: sumiyadi66@ gmail.com
}

\begin{abstract}
Abstrak
Relasi Antarteks dalam Pengkajian Sastra. Relasi antarteks terdapat dalam karya sastra yang di dalamnya membayangkan teks lain. Dalam mengkaji teks demikian, kita biasanya langsung mengkaitkannya dengan konsep intertekstual, padahal konsep tersebut berkaitan dengan teori pascastruktural sehingga dalam pengkajiannya, kita harus mengikuti prinsip-prinsip pascastrukturalisme. Relasi teks juga mensyaratkan kita untuk melakukan kajian bandingan, yang dalam kajian sastra dapat menggunakan konsep sastra bandingan. Kajian sastra bandingan tidak berkaitan dengan salah satu teori. Bahkan, teori apapum dapat dimanfaatkan untuk kepentingan sastra bandingan. Sehubungan dengan relasi teks dalam dunia sastra merupakan fenomena menarik, kemungkinan banyak pihak atau peneliti yang tertarik untuk mengkajinya. Oleh sebab itu, diperlukan landasan teori sastra yang kukuh dan relevan sehingga menghsilkan kajian sastra yang bermakna dengan kadar ilmiah yang dapat dipertanggungjawabkan. Penegasan ciri pembeda antara prinsip kajian sastra bandingan dan prinsip kajian intertekstual dalam tulisan ini merupakan upaya ke arah pengkajian sastra yang demikian.
\end{abstract}

Kata kunci: teks, intertekstual, pascastruktural, sastra bandingan

\begin{abstract}
Inter-textual Relation in Literary Studies. Inter-texts relation exista in literary works; one work shadows the other. In studying such texts we often immediately link them with the concept of intertextuality that belongs to post-structuralism. Texts relation also requires us to compare literary works using comparative literary study concepts. Comparative literary studies are not related with one specific theory. Any theory can be employed. Texts relation is an iteresting phenomenon that invites many to investigate. For this reason we need a grounded and relevant literary theory that will facilitate insightful and reliable literary studies. The difference between comparative literature principles and inter-textual studies principles are discussed in the article.
\end{abstract}

Keywords: texts, intertextuality, post-structuralism, comparative literature.

p-ISSN 1412-0712 | e-ISSN 2527-8312 